\title{
TOEZICHT OP DE VEILIGHEID IN MIJNEN DOOR MIJNWERKERS.
}

\section{II.}

Minder gunstig was de indruk der Pruisische Commissie van de uitkomsten der regeling in F'rankrijk.

In dit land danken de délégués à la sécurité des ouvriers mineurs hun bestaan aan de beweging die volgde op een stuk van de mijnwerkers te St. Etienne, dat, onder den titel "Cahier des doléances", in 1882 het licht zag. Waldeck-Rousseau en twee andèe députés dienden kort daarop een wets-ontwerp in, dat, na gedurende ruim 7 jaren tusschen Kamer en Senaat te

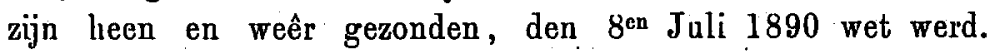
Sedert onderging deze wet eenige onbelangrijke wijzigingen, laatstelijk 5 Maart 1901. Een groot aantal ministerieele circulaires zijn er het uitvloeisel van geweest ${ }^{1}$ ). Laat de Engelsche wet de uitvoering van haar algemeen voorschrift, tot zelfs de wijze van verkiezing, het aantal bezoeken enz., aan de belanghebbenden over, in Frankrijk, het land waar - om met Marx te spreken - "jede Maus polizeilich administriert wird", is dit juist andersom: men kan zich geen bijzonderheid denken die niet bij wet of circulaire voorzien is.

De wet bepaalt dat er een délégué en een délégué suppléant zullen zijn in iedere "circonscription", welker grenzen door de préfets worden vastgesteld. Men heeft achtereenvolgens voorgesteld: een délégué per put; een op de zooveel mijnwerkers $(200,250,2000)$; een per onderneming; om te komen tot deze regeling, waarbij circonscription is: ieder gebied welks

1) 9, 19 Juli, 19 Augustus, 30 September 1890, 17 Februari 1891, gedeeltelijk opgenomen bij Cuvillier, Législation minière et contrôle des mines, Paris 1902, bl. 552 e. v.. 
ondergrondsche mijnwerken voor een volledig bezoek niet meer dan 6. dagen vorderen, en door én zelfden ondernemer worden ontgonnen. Mijnen met minder dan 25 mijnwerkers onder den grond kunnen vrijgesteld worden. De délégué suppléant vervangt zoo noodig den délégué.

De délégués worden telkens voor drie jạar verkozen door de mijnwerkers die onder den grond werken, Franschman en in het genot hunner staatkundige rechten zijn, en voorkomen op de laatste uitbetalingslijst vóór de verkiezing opgemaakt. Voor de verkiesbaarheid zijn bovendien de volgende vereischten gesteld: kunuen lezen en schrijven; vrij zijn van zekere veroordeelingen; leeftijd van 25 jaar; en 5 jaar gewerkt hebben in de circonscription, of in een naburige circonscription die door denzelfden ondernemer ontgonnen wordt. Ook oud-mijnwerkers kunnen verkozen worden, mits ze wonen binnen, of in de buurt van de circonscription.; 25 jaar oud, Franschinan, en in het genot hunner staatkundige rechten zijn; 5 jaar in de circonscription, of in een naburige, onder den groud hebben gewerkt, en dat het nog geen 10 jaar geleden is dat ze er, 't zij als mijnwerker of als délégué, werkzaain zijn geweest; niet reeds délégué in een andere circonscription zijn.

Bij nieuwe mijnen zijn verkiesbaar zij die elders in een mijn van dezelfde soort gedurende 5 jaar onder den grond hebben gewerkt.

Merken wij dadelijk op dat, anders dan in Engeland, de verkiezing van délégués verplicht is.

De wijze van verkiezing is uitvoerig geregeld. Het gaat als eel geheime, onmiddellijke verkiezing, waarbij het grootste deel van het schrijfwerk op het hoofd der mijnbesturen neêrkomt. Dezen zorgen voor de kiezerslijsten en -kaarten. De kiezers halen hun kaarten af bij den burgemeester der gemeente waar de verkiezing plaats heeft. De burgemeester is voorzitter van het stembureau. De verkiezing moet plaats hebben op een Zondag. Om bij eerste stemming verkozen te worden is noodig de volstrekte meerderheid en $\frac{1}{4}$ der stemmen van alle ingeschreven kiezers. $\mathrm{B} \ddot{j}$ herstemming is de betrekkelijke meerderheid voldoende, onverschillig het aantal uitgebrachte stemmen.

De taak van den délégué is. drieledig.

In de eerste plaats moet hij tweemaal per maand zijn ge- 
heele circonscription rond gaan; niet meer en niet minder.

In de tweede plaats moet hij onmiddellijk na een ernstig ongeluk (wat een ernstig ongeluk is zegt een circulaire) een onderzoek ter plaatse instellen. Hij zal daarom onmiddellijk ván een voorgevallen ongeluk mededeeling krijgen.

Eindelijk- moet hij den Staalsingenieur (of Controleur) bij zijn bezoeken vergezellen, wanneer deze zulks verlangt.

Het eerste en gewichtigste deel zijner taak omvat alle putten, galerijen en werkplaatsen, alsook de inrichtingen voor het ondergrondsch vervoer der arbeiders. De ministerieele circulaire van 19 Augustus 1890 omschrijft dit nader en noemt ook de inrichtingen voor luchtverversching. Voor de vraag of iets aan het toezicht van den delégué is onderworpen, beslist het al of niet van belang zijn voor de veiligheid der mijnwerkers. Hij heeft zich bij zijn bezoeken te gedragen naar de in de miju bestaande voorschriften van orde en veiligheid; hieruit vloeit in de toepassing voort, dat hij den bestuurder eener mijn den avond te voren zijn bezoek moet aankondigen, en dat deze altijd bepaalt door wien hij zal begeleid worden. Niet later dau den dag volgende op zijn bezoek, schrijft hij in een op de mijn aanwezig boek uur van aanvang en einde, den gevolgden weg, en zijn bevindingen. De ondernemer kan ziju opmerkingen hiernaast schrijven. Van alles wordt afschrift aan den Préfet en door dezen aan de Ingenieurs gezondeu. Laatstgenoemden moeten bovendien bij hun bezoeken het boek nazien.

Een bijzondere opdracht, die bij iuvoering der instelling ten onzent overweging zou verdienen, staat in verband met art. 7 van het Keizerlijk Decreet van 3 Jauuari 1813. Wanneer de Ingenieur een mijn in gevaarlijken toestand acht, en de ondernemer spreekt dit tegen, moeten er 3 deskundigen benoemd worden,' waarvan er één door den kantonrechter werd aangewezen. In plaats van dezen is de délégué gekomen.

Maakt de délégué zich aan grove nalatigheid schuldig; of aan: misbruik van gezag, of wordt hij veroordeeld krachtens artt. 41.4i en 4.15 Code pénal (werkstaking veroorzaken door geweld, bedreiging of bedrog), dan kan hij bij Besluit van den Préfet geschorst worden voor 3 maanden. Eeu ministerieele circulaire draagt in de eerste plaats aan de Ingenieurs op een 
oog in 't zeil te houden. Een onderzoek, en het hooren vau den délégué, moeten in ieder geval aan de schorsing voorafgaan. Binnen twee weken noet het schorsingsbesluit aan den Minister worden voorgelegd, die den délégué kan afzetten. De afgezette délégué kan de eerste drie jaren niet herkozen worden.

De délégués worden betaald door de ondernemers. Zij leveren aan den. Préfet de opgaven in der vergoedingen waarop zij aanspraak maken; de Ingenieurs zien deze opgaven na. Bij gaedkeuring krijgen zij uitbetaling van de schatkist, die het op de ondernemers verhaalt. Van dezen wordt het geïnd op dezelfde manier als een directe belasting.

Zooals boven gezegd, mag een circonscription poor een volledig bezoek harer ondergrondsche mijnwerken niet meer dan 6 dagen vorderen. Daar de délegué tweemaal per maand rond moet gaan, kan hij dus aan zijn gewone bezoeken nooit meer dan is dagen besteden. Maar de Préfet kan de circonscriptious wel kleiner maken (en doet dit in den regel). In verband daarmede is bepaald dat de Préfet voor iedere circonscription jaarlijks vaststelt hoeveel dagen de délégué hoogstens aan zijn bezoeken mag besteden. Voor concriptions met minder dan 1200 arbeiders stelt hij het minimum der in een maand te genieten vergoeding vast. Waar meer arbeiders zijn, is het minimum der vergoeding 10 dagen per maand. De vergoeding wordt namelijk per dag berekend. De Préfets stellen insgelijks jaarlijks voor iedere circonscription vast hoeveel de vergoeding per dag zal bedragen, waarbij zij als maatstaf moeten aannemeu het dagloon van een goed betaalden mijnwerker onder den grond.

De bezoeken in geval van een ongelnk, of ter begeleiding van den Ingenieur, worden afzonderlijk betaald.

De strekking dezer vrij ingewikkelde regeling is om eenerzijds den délégué aan te moedigen tot een geregeld bezoek der mijn, andrerzijds zooveel mogelijk te voorkomen dat hij een vergoeding. geniet voor meer dagen dan hij aan zijn bezoeken besteedt. De délégué zal nooit alleen van deze vergoedingen kunnen leven; hij zal er altijd het beroep van mijnwerker of een ander (mits hij oud-mijnwerker is) bij moeten uitoefenen.

Straf is bepaald tegen hen die de uitvoering der wet bemoeielijken of haar voorschriften overtreden. 
Wanneer we den Franschen délégué, zooals hij uit bovenvermelde bepalingen te voorschijn treedt, vergelijken met den Britschen working-man inspector, dan zien we éen belangrijk versobil: De verkiezing van laatstgenoemde is vrij gelaten;'de arbeiders, zelven betalen hem, tenminste volgens de wet. $\mathrm{Hij}_{\mathrm{j}}$. mag eens per maand de mijn bezoeken. Ziju Fransche ambtgenoot moet tweemal in de inaand de mijn rond: Zijn verkjezing is niet aan de willekeur der arbeiders overgelaten. De ondernemer betaalt hem.

Overigens stemmen beiden hiexin overeen, dat hun bevoegdheid uitsluitend waarnemend is: "een oog in de mijn," "visiteurs-rapporteurs." Ze hebben, ook den arbeiders, niets te bevelen: Ongekeerd heeft niemand hun iets te bevelen. Ook niet in Frankrijk; al zijn de Ingenieurs verplicht vergrijpen der délégués an deu Préfet te melden.

De bepaling der Fransche wet dat de délégué geen mijnwerker meer behoeft te zijn, is niet zonder uitwerking gebleven. In: 1895 , dus na de tweede verkiezing, waren niet minder dau 78 of $29 \mathrm{pCt}$. der délégués en 25 of $10 \mathrm{pCt}$. der suppléauts oud-mijnwerkers. 182: délégués $(68 \mathrm{pCt}$.) en 225 suppléants $(85$ pCt.) werkten in de mïn waar ze verkozen waren, 6 délégués en 10 suppléants in een andere. In het geheel waren el 294 circonscriptions. In 28 hiervan hadden de mijnwerkers afgesproken geen délégués te verkiezen. ${ }^{1}$ )

Het is niet gemakkelijk zich een oordeel te vormen over de uitkomsten van de Fransche wetgeving op dit stuk.

De oijfers spreken als volgt.

Omgekomen per 10.000 mijnwerkers onder den grond in

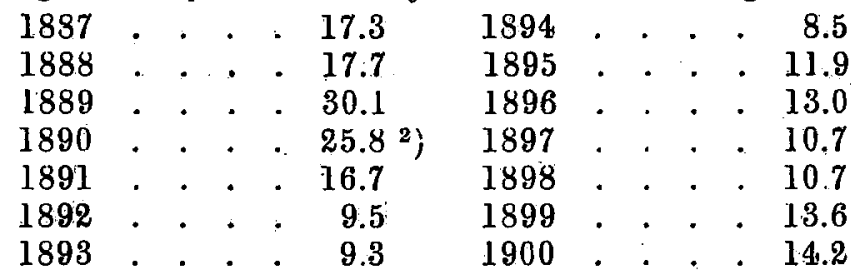

Andere opgàve (3e bijlage van het Bericht der Pruisische Cornmissie):

1) Rapport Félix Martin, Sénat 14 Déc. 1896.

2) (In Juli van dit jaar de dêlégués ingevoerd:) 


$$
\left.\begin{array}{lll}
1879-1884 & \text { gemiddeld } & 14.2 \\
1885-1890 & " & 15.3 \\
1891-1896 & 12.6
\end{array}\right\} \text { vó́r de wet. }
$$

Aan een onderzoek naar den toestand in de mijnen door een Commissie uit de Kamer in $1896^{1}$ ), ontleen ik de volgende aauhalingen.

M. Weiss, Ingénieur des mines, verklaart de délégués onbevoegd oin over inrichtingen voor luchtverversehing te oordeelen.

M. Fèvre, Ingénieur des mines: "wanneer het houtwerk niet deugt, durft de délégué er de aandacht niet op te vestigen, uit vrees van kameraden die er schuld aan hebben onaangenaam te zijn. - Er ziju weinig kundige délégués."

M. Beugnet, délégué, zegt "dat de gekozen délégué dadelijk voor het slechtste werk wordt gezet en een hongerloon verdient. - Wanneer een délégué wil afdalen, moet bij 24 uren tevoren den ondernemer hiervan verwittigen. In dien tusschentijd maakt laatstgenoemde de mijn in orde en verstopt de zwakke punten. - De persoon die den délégué vergezelt, 'bespiedt hem , kijkt of de arbeiders klagen en of de délégué vragen stelt."

M. de Castelnau, Ingénieur en chef: "De wet levert hier geen moeielijkheden op. Ik geloof niet dat de délégués voldoende onderricht zijn om te begrijpen wat er in de mijnen omgaat. In hun verslagen wijzen ze op een gebroken stuk hout, een slecht onderhouden galerij, anders niet. - Ze konden toch goede diensten bewijzen."

M. de Billy, Ingénieur: "Wij kunnen zeer goed met de délégués opschieten. Sedert drie jaren heeft émaal een délégué mijngas ontdekt, waarvan de aanwezigheid niet bekend was. Gewoonlijk blijven ze met hun opmerkingen laag bij den grond, en spreken weinig over de mijn in haar geheel of de veiligheid in het algemeen."

M. Bouillin, délégué: "Ik ben délégué en barbier. Het. bestuur van de mijn wordt op de hoogte gehouden welke mijnwerkers zich bij mij laten scheeren."

M. Tauzin, Ivgénieur en ehef: "De délégués bewijzen goede diensten voor bet toezicht op de onderdeelen der ontginning. Ik ken ondervemers die de instelling toejuichen. Maar men

1) Rapport Lacombe; z. boven: (Economist van Juni.) 
moet niet te veel van hen verlangen, niet hun meening vragen over de groote rampen of over het beste stelsel van ontginning. De man die lang in een mijn geleefd heeft, kent beter het delfstoffelijk voorkomen, de omstandigheden waronder de kool wijkt. Hierover kan men met vrucht zijn meening vragen."

M. Mazars, délégué: "De ingenieurs zien in ons tegenstanders in plaats van medewerkers. De wet geeft niets."

Het meergenoemd Bericht der Pruisische commissie heeft van drie mijn-eigenaars ongunstige mededeelingen over de instelling ontrangen. De délégués misten de vereischte kunde. Ze maakten alleen aanmerking op beambten der mijn, nooit op kameraden. Ze waren de onder-officieren van het socialisme of althans van de stakings-vereenigingen.

Nog een enkele aanhaling uit dit Bericht.

De Directeur-Generaal van Anzin (de grootste mijn-maatschappij van Frankrijk) gelooft niet dat de délégués ongelukken helpen voorkomen, omdat de Staatsingenieurs voldoende:hiervoor zorgen. Toch zijn de gekozenen doorgaans goede arbeiders.

De Directeur-Generaal van een mijn-maaischappij in Pas-deCalais legt de kenschetsende verklaring af, dat sedert de macht der arbeiders-vereenigingen gebroken is, alleen personen worden gekozen die de maatschappij aangenaam zijn.

$\mathrm{Bij}$ den over het algemeen ongunstigen indruk dien de stellers van dit Bericht van de werking der Fransche wet hebben gekregen, moet men niet uit het oog verliezen dat zij, zooals zij zelf erkennen, slechts met mijneigenaars en ambtenaren, niet met mijnwerkers hebben gesproken. In hetzelfde Bericht wordt een ambtelijke statistiek medegedeeld volgens welke in 1892:

15681 verslagen geen opmerkingen, eu

456 onjuiste opmerkingen behelsden. Maar niet minder dan 1239 gaven den ondernemer,

145 den Ingenieur en

2 den Préfet aanleiding tot het nemen vau maatregeleu.

De heer Emile Harze, die op last van den Belgisehen Minister Nyssens een onderzoek in het Noorden van Frankrijk instelde, kwam tot de slotsom dat de instelling daar geen uitwerking had, noch ten goede noch ten kwade.

Med moet bij het beoordeelen hiervan de omstandigheden waaronder de wet tot stand $\mathrm{kwam}$, in aanmerking nemen. $\mathrm{Na}$ 
7. jaren door mijneigenaren en ook door veel Ingenieurs bestreden, te zijn, was zij bij hare invoering reeds gehaat. De omstandigheid dat de kosten en veel administratief gemaal aan eerstgenoemden werden opgelegd, deed aan deze stemming geen goed. Voorts waren de maatschappelijke verhoudingen in de Fransche mijunijverheid gedurende het laatst verloopen tiental jaren hoogst. ongunstig; we zagen hier eenige maanden geleden de bewijzen van. Het is niet te verwonderen dat een democratische instelling als deze den weêrslag ondervindt van den geest van bitterheid en wantrouwen die daar heerscht.

Vooreerst spreekt die geest uit de klachten der arbeiders. Uit de verklaringen der ondernemers blijkt over het algemeen, dat de angst voor den politieken invloed der délégnés overdreven is geweest. Die angst was van te voren algemeen, maar thans ontmoet men zelden klachten hierover. In 1899 , dus na de eerste 8 jaren, was viermaal een délégué afgezet en tweemaal een geschorst moeten worden; hiervan slechts twee ,wegens politieke bemoeiingen.

Maar de arbeiders klagen luide over tegenstand door de ondernemers bij de uitvoering der wet; tegenstand welke zij door gebrek aan aaneensluiting niet weten te overwinnen. Op de verkiezingen wordt op verschillende 'manieren druk uitgeoefend. De laaste wetswijziging was tegen dit misbruik gericht. Onder het voorwendsel van den délégné te helpen, zeggen de mijnbeambten hem zijn verslag voor. Ook zijn alle eisclien der mijnwerkers gericht op meerdere onafhankelijkheid der délégués. Zij willen grootere circonscriptions, waardoor de délégué de geheele maand in beslag zou worden genomen; dat de grenzen van verkiesbaarheid worden uitgebreid; en dat.de délégué zelf de persoon moge anwrijzen die hem zal begeleiden.

Het verschil met Engelsche toestanden is hier treffend. Nog in een ander opzicht bestaat groot onderscheid, n.l. in het oordeel over de bekwaanheid van den-mijn werker. Tot het vaststellen van de aanwezigheid van mijngas b.v. achten de Engelsche Ingenieurs de mijnwerkers-afgevaardigden bevoegd, de Fransche niet.

De hier aangestipte punten staan meer in verband met Fransche toestanden dan met de instelling op zichzelve, en wanneer men nu tracht de laatste afgescheiden van de eerste te beschouwen; 
dan is er geen reden om over haar uitkomsten een ongunstig oordeel te vellen. De boven meegedeelde eijfers wijzen toch maar, evenals in Engeland, op een vrij belangrijke vermindering van het antal ongelukken sedert dat het mijnwerkers-toezicht bestaat. In het tweede jaar dat de wet werkte, gaven 1386 verslagen aanleiding tot het nemen van maatregelen ter verbetering van de veiligheid (zie boven). Vandaar dan ook dat velen over de werking der wet guustig oordeelen ').

ln hoeverre het aan de wijze van regeling te wijten is dat de uitkomsten in Frankrijk minder gunstig zijn dan in Engeland, is moeilijk te zeggen. Het Pruisische Bericht acht de verplichte verkiezing in alle mijnen een fout; in veel mijnen is er voor délégués niets te doeu, waardoor dezen er toe komen allerlei nuttclooze kleinigheden in hun verslagen op te nemen. De verkiesbaarheid van oud-mijnwerkers en de betaling door de ondernemers worden eveneens afgekeurd. Intusschen wijt ook genoemd Bericht de naar zijn oordeel ongunstige gevolgen der wet aan eigenaardig Fransche toestanden, en aan de mindere behoefte aan de instelling door de goede inrichting van het Staatstoezicht, zooveel vollediger dan in Engeland.

Bleek het beginsel van mijnwerkers-toezicht in Frankrijk en Engeland voor zeer verschillende uitwerking vatbaar, tot nog een geheel ander stelsel $\mathrm{kwam}$ de wetgever in Belgie.

Reeds lang verscheen de invoering van dit toezicht op de programma's der Belgische mijnwerkers-bijeenkomsten. De mijnen te Mariemont en Bascoup gaven den wetgever het goede voorbeeld door de instelling in 1887 van conseils de conciliation, welks leden, door de arbeiders gekozen, met zoodanig toezicht werden belast. Dezen werkten na korten tijd tot algemeene tevredenheid.

Verschillende voorstellen van wet bereikten de Kamer, waarvan dat van Minister Nijssens, ingediend 30 April 1896, den $11^{\text {en }}$ April 1897 wet werd.

Volgens deze wet worden de délégués à l'inspection des mines benoemd door den Minister. - Deze bepaling vond hevigen tegenstand bij de linkerzijde in Kamer en Senaat.

1) Dr. Hirsch in Abgeordnetenhaus 29 Nov. 1899. Oordeelvellingen aangehaald bij Taillandier bl. 219 e. v., Dumolard, bl. 140 e. v., en tal van sprekers in de verschillende parlementen. 
De arbeiders-députés, en velen met hen, onthielden zich hierom van stemming over de geheele wet. Dezen hadden natuurlijk verkiezing door de mijnwerkers verlangd, waarvan de Regeering en de meerderheid niets weten wilden. De Regcering verdedigde haar voorstel roornamelijk met te wijzen op het gestadig afnemen van ongelukken onder het bestaande Staatstoezicht. De délégués moesten zich aan dit toezicht aansluiten, hiermede geen tegenstelling vormen. Daarom werden het, volgens Minister Nijssens, nog geen ambtenaren, want hun anstelling is tijdelijk, ze genieten geen eigenlijk gezegd traktement en geen pensioen.

De Minister kiest uit een voordracht van twee personen, opgemaakt door de afdeelingen der Conseils de l'industrie et du travail voor de steenkolen; lichamen, die zijn te vergelijken met onze Kamers van Arbeid en eveneens voor de helft uit arbeiders, voor de helft uit werkgevers zijn samengesteld. Voor het maken dier voordracht moeten minstens de helft der leden eener Afdeeling medestemmen. De-stemming is geheim en de volstrekte meerderheid beslist.

Om voorgedragen te kunnen worden moet men zijn: Belg; 30 jaar oud; sedert minstens 10 jaren als mijnwerker of opzichter in de circonscription, of in een naburige, een of meer soorten van mijnarbeid onder den grond verrichten waarvoor een leertijd is voorgeschreven, met uitsluiting van allen daglooners- of hulp-arbeid; kunnen lezen en schrijven en de vier regels der rekenkunde kennen; eenigszins bekend zijn met het raadplegen van mijnkaarten waar alleen op voorkomen lagen die vlak of steil gelegen zijn; niet failliet zijn verklaard enz., en vrij zijn van veroordeelingen wegens overtreding van bepalingen van mijnpolitie en van zekere andere veroordeelingen. - Op 25-jarigen leeftijd en na 5 jaren mijnarbeid kunnen voorgedragen worden zij die een getuigschrift van bij K. B. aan te wijzen nijverheids-scholen bezitten.

De benoembaarheid van opzichters is een Belgische uitvinding. Dit zijn intusschen geen eigenlijke beambten, maar met zeker opzicht belaste arbeiders, die per dag of week betaald worden. Verschillende der vereischten voor benoembaarheid maken een klein examen noodig; hierop ziet een commissie toe, bestaande uit den Directeur-Général des mines, een hoofd- en een gewoon 
ingenieur ${ }^{1}$ ). Deze vereischten vonden ook veel afkeuring: het mijnwerkerstoezicht moet practisch zijn; men moet niet de min of meer geletterden onder de arbeiders uitzoeken, het wetenschappelijk ouderzoek berust bij de Ingenieurs ${ }^{2}$ ). - Anders dan in Frankrijk zijn dus gewezen mijnwerkers buitengesloten.

Wanneer geen twee benoembare personen worden voorgedragen benoemt de Minister er zonder voordracht twee die de genoemde vereischten bezitten.

De benoeming geschiedt voor 3 jaar, maar dezelfde personen kunnen herbenoemd worden. De délégué die niet herbenoemd is, moet, om weêr te kunnen worden voorgedragen, eerst minstens een jaar mijnwerker geweest zijn.

$\mathrm{Bij}$ tusschentijds openvallen wordt een délégué benoemd of die eener naburige circonscription tijdelijk met de waarneming belast.

De circonscriptions worden iedere 3 jaar bij K. B. vastgesteld. Er zijn er thans 38 , ieder met gemiddeld 2300 arbeiders ${ }^{3}$ ). Voorloopig zijn er alleen délégués voor de kolenmijnen, maar bij K. B.- kunnen ze voor andere mijnen worden ingevoerd.

In België ziju de délégués niet, zooals in Frankrijk en Engeland, arbeiders die nu en dan de mijnen rondgaan, maar ze worden door huu werkzaamheden geheel in beslag genomen. $\mathrm{Er}$ is er slechts één voor iedere circonscription. Ze genieten een jaarlijksche toelage van 1800 francs, benevens vergoeding van reiskosten ${ }^{4}$ ). Ze houden dus op mijnwerker te zijn. Onvereenigbaar met liun ambt is het lidmaatschap der Conseils de prud'hommes, de l'industrie et du travail, provinciaux of communaux, Kamer en Senaat; ook mogen ze geen handel drijven, noch hun vrouw of met hen samenwonende verwanten. De eenige band met de mijn waar ze werkten, is dat ze behouden hun aanspraken op de onderstandskas; een zeer nuttige bepaling, die in de Fransche wet vergeten is.

$\mathrm{Zij}$ moeten minstens 18 bezoeken per maand aan de ondergrondsche mijnwerken hunner circonsoriptions brengen. Juist als in Frankrijk moeten ze hiervan aanteekening doen in een register,

1) Min. Besluit van 30 Jan. 1898.

$\left.{ }^{2}\right)$ Brief van een mijn-ingenieur, voorgelezen in de Chambre des Repr. 17 Febr. 1897.

3) K. B. van 7 Oct. 1900 .

4) Beide geregeld bij K. B. van 12 Dec. 1897. 
waarin de ondernemer zijn tegen-opmerkingen kau plaatsen. Dè délégué stuurt zelf afschrift zijner opmerkingen aan den Ingenieur ${ }^{1}$ ).

Hij zal zich gedragen naar de voorschriften van orde en veiligheid die in de mijn gelden. Hij kan eischen, en nooit weigeren, begeleid te worden. manr zijn gids zal zich desverlangd "een oogenblikje verwijderen, ten einde den arbeiders gelegenheid te geven vrijuit met den délégué te spreken."

Buiten zijn gerrone bezoeken, zal de délégué aau het onderzoek deelnemen naar de oorzaken van een ongeluk, en de overtredingen aangeven van die wetten en voorschriften op welker uitvoering de mijningenieurs hebben toe te zien. Deze laatste nuttige bepaling ontbreekt in de Fransche wet.

Zij zullen zich in het algemeen voegen naar de orders van de Ingenieurs. Met dezen zullen zij zich zooveel mogelijk in verbinding stellen. Dit punt wordt in het licht gesteld door de Circulaire van 24. Februari 1898, waarin het karakter der délégués nader wordt uiteengezet. Hun bevoegdheid omvat, blijkens deze Circulaire, behalve de ondergrondsche werken ook de lampenkamers. Bij alles wat zij doen, hebben zij uitsluitend toe te zien en te berichten, orders mogen zij niet geven.

Art. $18^{2}$ ) voorziet het geval, dat bepaalde omstandigheden een onderzoek in het belang van gezondheid of veiligheid wenschelijk doen schijnen; b.v. er heerscht droes onder de paarden in de mijn. De Minister kan zoodanig onderzoek doen verrichten door bepaald aan te wijzen personen.

De ongeschikt geworden of zijn plichten verwaarloozende délégué kan worden ontslagen. Met eenige andere strafbepalingen is het bovenstaande in hoofdzaak de inhoud van de Belgische wet.

Beschouwt meu deze bepalingen in haar geheel, dan ziet men dat wat hier geschapen is, in beginsel versehilt van de instelling zooals zij in Engeland en Frankrijk bestaat. De Belgische délégués zijn eigenlijk geen idélégués", maar ambtenaartjes, door den Minister uit de arbeiders gekozen.

1) In Belgie, waar ook de wet van 1810 , hoewel belangrijk gewijzigd, nog geldt, is het Staatstoezicht opgedragen aan 16 hoofdIngenieurs en 29 gewone Ingenieurs. Br is gemiddeld één Ingenieur op de 3500 mijn werkers.

$\left.{ }^{2}\right)$ dat eigenlijk in deze wet niet op zijn plaats is. 
De wet trad volledig in werking in Mei en Juni 1898. De grootste moeielijkheid leverde op het vinden van mijnwerkers die 10 jaar in eene circonscription, of in een naburige, waren werkzaam geweest (het Regeeringsontwerp had 5 jaar voorgesteld). 7 van de 38 waren opzichters. Bij de tweede benoeming, in 1901, werden 29 herbenoemd; 2 hadden een betere betrekking gevonden. 31 werden op voordracht van de Conseils de l'industrie et du travail, 7 zonder voordracht benoemd.

Per 1000 arbeiders onder den grond werden gedood:

\begin{tabular}{|c|c|c|c|c|c|}
\hline in 1891 & & 17.29 & in 1896 & . & 13.82 \\
\hline$\| 1892$ & & 37.38 & " 1897 & . & \rfloor 3.13 \\
\hline " 1893 & & 14.37 & " 1898 & . & $\left.17.06^{1}\right)$ \\
\hline " 1894 & . & 20.22 & " 1899 & . & 10.93 \\
\hline " J 895 & . & 15.78 & " 1900 & . & 12.16 \\
\hline
\end{tabular}

Opgemerkt moet worden dat in 1898 drie buitengewoon ernstige ongelukken voorvielen.

De Directeur-Général des mines zingt in zijn jaarverslagen in de Statistique des mines den lof der délégués. In het begin liet de algemeene ontwikkeling veel te wenschen. De Ingenieurs hebben hen echter op streek gebracht; en nu zijn zij den Ingenieurs van groot nut, vooral voor het bezoeken onmiddellijk nadat een ongeluk heeft plaats gehad; de ondernemers zijn dan ook uitgenoodigd om dadelijk van een ongeluk kennis te geven aan den bevoegden délégué, wartoe de wet hen niet verplicht. Op de werkzaamheid der door de mijnbesturen aangestelde opzichters hebben zij een gunstigen invloed. Ze leggen over het algemeen meer bezoeken af dan de wet hun beveelt. De groote vraagstukken, zooals de luchtverversching, gaan boven hun bevatting, maar over de onderdeelen kunnen ze goed oordeelen, met name over het stutwerk. Ofschoon de arbeiders liever gekozen délégués hadden gehad, schenen in 1899 reeds "alle moeielijkheden uit den weg geruimd; het verzet schijnt opgegeven en de beste verstandhouding te bestaan met werkgevers en arbeiders. De oorzaak hiervan mag worden toegeschreven aan den rechtvaardigheidszin en rechtschapenheid, die alle délégués, onverschillig van welke staatkundige overtuiging, bezielt."

1) Jaar der invoering.

Econ. 1903. 
Dit alles klinkt "too good to be true," en is warschijnlijk bestemd om te bewijzen dat de instelling, die overeenkomstig de denkbeelden van dienzelfden Directeur-Général is ingevoerd, in het bijzonder wat betreft de benoeming, in hooge mate voldoet.

De Pruisische commissie kon bij haar bezoek iu 1899 nog niet veel over de uitkounsten der wet vernemen, maar oordeelt dat deze niet genoeg waarborgen oplevert voor zelfstandige plichtsbetrachting der délégués. "Het ligt in den aard der zaak," schrijft zij, "dat de lust voor mijnarbeid bij hen meer en meer zal afnemen. Er is daarom wel eeuige grond voor het vermoeden, dat sommige délégués gedurende hun ambtstijd alles zullen trachten te vermijden, wat hun herbenoeming zou kunnen verijdelen, en te dien einde menige overtreding van voorschriften der wet of der mijnpolitie door arbeiders of bebeambten zullen door de vingers zien."

Inderdaad is niet aan te nemen, dat na den hardnekkigen strijd voor gekozen délégués in en buiten de Kamer, de arbeiders met deze ondergeschikten der Ingenieurs tevreden zijn. De voordracht door de Conseils de l'industrie et du travail kan dit niet goedmaken, omdat de daarin zitting hebben arbeiders gezegd worden onder de plak der werkgevers te zitten. Meermalen ook hebben de arbeiders voor deze voordracht niet medegestemd. Alleen blijkt uit de verslagen van den DirectearGénéral des mines, dat zelfs deze fletse nabootsing van het mijnwerkers-toezicht goed is voor het opmerken van kleine verzuimen bij de onderaardsche ontginning en voor den ijver der opzichters.

Evenmin als de instelling gelijk zij in Belgie bestaat, van het mijnwerkerstoezicht een goed beeld geeft, was dit tot voor korten tijd het geval met de Vertrauensmänner in de Pruisische Staatsmijnen. Deze werden ingevoerd kort na het Congres te Berlijn over. arbeiders-vraagstukken in 1890. Deze vertegenwoordigers der wijnwerkers waren in het algemeen bestemd om grieven en wenschen der arbeiders aan de besturen der Staatsmijneu over te brengen. Hun opdracht was dus veel algemeener dan het toezicht op de veiligheid, en met dit laatste liebhen ze zich weinig ingelaten. De Vertrauensmänner hebben niet beantwoord aan de gestelde verwachtingen. $\mathrm{Zij}$ brachten de 
eischen der socialistische mijnwerkers-bevolking over, en toen de arbeiders zagen dat dit geen practische uitwerking had, verloren zij hun belangstelling voor deze vertegenwoordiging.

De omstandigheid dat in de Duitsche mijnen meer ongelukken plaats hebben dan in én der hiervoor genoemde landen, en dat het aantal, in tegenstelling met die lauden, stijgende is, heeft echter aan de beweging voor mijnwerkers-toezicht in Duitschland kracht bijgezet en de aandacht der openbare meening hierop gevestigd. Reeds hadden de mijnwerkers in de Staatsmijnen in Silezie aangeboden zelf de kosten te dragen, indien tot de invoering werd overgegaan. Ook in den Rijksdag werd herhaaldelijk op een proefneming in de Staatsmijnen aangedrongen. Hieraan heeft de Pruisische Regeering gevolg gegeven door te Saarbrücken bij wijze vau proef aan de Vertrauensmänner zoodanig toezicht uitdrukkelijk op te dragen.

Dezen worden verkozen, één in iedere Steigerabtheilung, door de meerderjarige arbeiders die minstens 3 jaren te Saarbrücken werkzanm zijn. Voor de verkiesbaarheid is 25-jarige leeftijd en een verblijf van minstens 5 jaren op eenzelfde mijn te Saarbrïcken vereischt. Gekozen is wie de meerderheid der uitgebrachte stemmen op zich vereenigt. De duur der opdracht is 2 jaren, maar kan vroeger eindigen, o. a. door ontslag uit den Staatsmijndienst.

Dezen Vertrauensmänner is sedert 1 Januari 1903 opgedragen iedere maand hun gebied rond te gaan op een dag te hunner keuze, mits den avond tevoren den Abtheilungssteiger aangezegd. Ook worden ze door dezen of een anderen beambte begeleid. Hun opmerkingen moeten zij in een boek schrijven. Zij zijn bovendien gerechtigd, begeleid als voren, een onderzoek in te stellen wanneer een ongeluk heeft plaats gehad. Voor de maandelijksche bezoeken ontvangen zij 5 mark per keer. De bezoeken na een ongeluk worden afzonderlijk betaald.

Vindt de Obersteiger geen anleiding om gevolg te geven aan voorstellen van den Vertrauensmann, dan moet hij het boek met de opınerkingen van dezen laatste aan den Directeur der mijn voorleggen. Deukt deze er evenzoo over, dan wordt het boek aan den Vorsitzender der Bergwerksdirektion voorgelegd.

Het Bestuur der Staatsmijnen te Saarbrücken, waaraan ik de mededeeling dezer regeling dank, acht den tijd harer 
werking te kort om over de uitkomsten eenig oordeel te vellen.

Behalve iu Pruisen bestaat nog sedert kort een soort mijnwerkers-toezicht in Beieren. Hier wordt in de Staatsmijnen (en één bijzondere miju) schadeloosstelling toegekend aan den vertegenwoordiger der arbeiders die den Berginspektor bij zijn bezoeken wil begeleiden. Er wordt veel gebruik van gemaakt.

In Saksen werd het mijnwerkerstoezicht bij wijze van proef in 1900 ingevoerd.

Deze "Sicherheitsmänner" worden verkozen door vertegenwoordigers der arbeiders (de Kassenmitglieder van het Bestuur der Ziekenkas) $\mathrm{Om}$ een tweeledige proef te nemen, is de wijze van verkiezing op de mijnen te Freiberg anders geregeld dan op die van Zauckerode. Op de eerste kunnen verkozen worden alle mijnwerkers die aan zekere algemeene vereischten voldoen (leeftijd van minstens 35 jaren, 5 jaren op de mijn gewerkt hebben, enz.). Te Zauckerode geschiedt de verkiezing uit een grooter of kleiner aantal door het mijnbestuur aan te wijzen arbeiders.

Overigens behelst de Saksische regeling geen nieuwe voorschriften. De opdracht geschiedt voor een jaar, en daarna moet de gekozene 3 jaar gewoon mijnwerker zijn geweest om weêr gekozen te kunnen worden. Hij kan gedurende dat jaar slechts om bepaalde, in de wet genoemde, redenen ontslagen worden. Hij gaat rond zoo vaak hij wil (in Zauckerode is een verplicht aantal bezoeken voorgeschreven). Het boekje waarin hij zijn opmerkingen schrijft, woet minsteus eenmaal per week door het mijnbestuur worden nagezien.

De officieele verslagen ') schorten in 1901 hun oordeel over de instelling op. In 1902 wordt er reeds zeer gunstig over geoordeeld. Ze droeg bij tot vermeerdering der veiligheid, zoowel onmiddellijk als middellijk, doordat opzichters en arbeiders opmerkzamer werden op het in acht nemen der veiligheidsmaatregelen. Aan alle opmerkingen der Sicherheitsmänner was gevolg gegeven. Tot meeningsverschillen met het opzichterspersoneel had dit nooit anleiding gegeven. De meeste opmerkingen betroffen onvoorzichtigheden der mijnwerkers. Een

1) Jahrbuch für das Berg- und Hüttenwesen im Kön. Sachsen, 1901 B 108, 1902 B 107, 133 e. v.. 
bijzondere mijn had het voorbeeld der Staatsınijnen nagevolgd.

$\mathrm{Er}$ is reden om aan te nemen dat over eenige jaren alle bijzondere mijnen in Duitschland aan dit toezicht zullen moeten gelooven. $\mathrm{Zij}$ verkeeren toch wat de veiligheid betreft, in veel ongunstiger toestand dan de Staatsmijnen.

Ziehier een staatje van de verongelukten per 1000 mijnwerkers (boven en onder den grond) in de Staatsuijuen te Saarbrücken en in Silezie, en die in de bijzondere mijnen van W'estfalen ${ }^{1}$ ).

$\begin{array}{lccc} & \text { Saarbrüken } & \text { Silezie } & \text { Westfalen } \\ 1894 & 2.03 & 1.94 & 2.36 \\ 1995 & 2.23 & 2.58 & 2.60 \\ 1896 & 1.66 & 3.27 & 2.53 \\ 1897 & 1.56 & 2.18 & 2.59 \\ 1898 & 1.66 & 2.57 & 3.31 \\ 1899 & 1.74 & 2.21 & 2.54\end{array}$

Aantal ongelukken in alle bijzondere mijnen per 1000 arbeiders: $\quad$ in 1897: 2.47, in 1898: 3.03 ;

en in de Staatsmijnen: in 1897: 1.80, in 1898: $2.09^{2}$ ).

Hiermede zijn de in het buitenland opgedane ondervindingen met het toezicht op de ondergrondsche veiligheid uitgeoefend door mijnwerkers, afgehandeld. In Engeland bleek de instelling alleen goede uitkomsten op te leveren. In verband met het gebrekkig Staatstoezicht in dat land, is zij er gaandeweg onmisbaar geworden. In Frankrijk is het moeielijker, te midden van de vele staatkundige vooroordeelen, ten aanzien van de werking der wet achter de waarheid te komen. Toch meen ik dat ook daar de instelling een goede uitwerking heeft gehad, terwijl de vooraf gevreesde slechte gevolgen slechts bij uitzondering zijn ingetreden. In Belgie heeft men aan dit toezicht een geheel ander karakter gegeven, waarvan de nadeelen me niet toeschijnen door de voordeelen te worden opgewogen; overigens werkt de wet hier nauwelijks $4 \frac{1}{2}$ jaar, dus wel wat kort om over de gevolgen een eindoordeel te vellen.

Over het algemeen pleiten de elders opgedane ondervindingen dus vóór het hier besproken toezicht. De proefnemingen in

1) Weiss, l'Exploitation des mines par l'Etat, Paris 1901, bl. 52.

2) Minister Brefeld in Pruisisch Abgeordnetenhaus, 27 Feb. 1899. 
Duitschland duiden er op dat ook daar de invoering slechts een vraag van tijd is. En wanneer het in Westfalen bestaat; geloof ik dat het moeielijk in Limburg achterwege zou kunnen blijven. Nog beter zou het zijn onzen oostelijken naburen in dezen vóbr te zijn.

De vraag rijst dan welk van de hierboven behandelde stelsels navolging verdient. Niet het Belgische, zou ik meenen. Hieraan kleven twee bezwaren: de benoeming door de Regeering en het onttrekken der benoemden aan den arbeid in de mijnen.

Wat het eerste betreft, het karakter zelf der instelling brengt mede, dat hier verkiezing moet plaats hebben, en geen benoeining. Alleen de gekozenen der arbeiders kunnen geacht worden tret volle vertrouwen te bezitten, waar het in de eerste plaats op aankomt. Dat men in Belgie, bij toestanden als b.v. de Borinage te zien geeft, hiervoor teruggedeinsd is, moge verklaarbaar ziju; deze op bescherming der arbeiders gerichte wet mocht evenwel de stemmen der Belgische arbeiders niet verwerven. Bij ons, waar de mijnnijverheid nieuw is, waar zulke toestanden niet bestaan, bestaat dit bezwaar in ieder geval niet. Hoe kan ook de Minister deze personen benoemes? In de bijzondere mijnen zal hij zich wel moeten doen voorlichten door de mijnbestuurders, in dezen slechte raadgevers. En waar de Staat zelf werkgever is, verdient het nog sterker afkeuring door de benoeming reeds een zekere afhankelijkheid van de Regeering te scheppen.

Aanwijzing door het bestuur, of verkiezing door de leden, van mijnwerkers-vereenigivgen, zooals in Engeland, ware m. i. het beste stelsel. Maar door het ontbreken van zoodanige vereenigingen ten onzent, is dit buitengesloten. Daarom beveelt zich van zelf aan een verkiezing als voor de Kamers van Arbeid plants heeft. De regeling is in dit geval niet moeielijk. Kiezerslijsten zijn de registers, die de werkgever reeds krachtens art. $31 c$ van het Reglement van 1877 moet houden. Kiesdistricten ziju de gebieden, die toch vastgesteld moeten worden, waarover zich het toezicht telkens van één persoon uitstrekt.

Het karakter der instelling brengt evenzeer mede, dat de gekozenen niet aan den arbeid in de mijnen moeten worden onttrokken. Het bestuur der mijnen te Mariemont, in België, waar het mijnwerkerstoezicht zoo algemeen voldeed, hecht 
hierann de grootste beteekenis. ${ }^{1}$ ) Evenzoo Dr. Hirsch te Berliju. ${ }^{2}$ ) Juist door zelf den meesten tijd mijnarbeid te verrichten en door dagelijkschen omgang met kameraden, is de mijnwerker in staat het soort toezicht uit te oefenen dat hier gevraagd wordt.

In het algemeen zou ik dus meenen, dat de mijnwerkeropzichters, of welken naam zij mogen krijgen, verkozen behooren te worden, en dat zij mijuwerker moeten blijven. Op dit laatste zou alleen een uitzondering moeten gemaakt worden ten behoeve van gewezen mịnwerkers, die verkozen zijn geweest. Anders zou de verkozene, door ontslagen te worden als mijnwerker, tevens zijn baantje verliezen. Dit zou hem te zeer af hankelijk maken van hen, op wier beleid hij heeft toe te zien.

Kiezers zullen moeten zijn alle meerderjarige Nederlanders die onder den grond werken.

Voor de verkiesbaarheid zal vereischt moeten worden, behalve de hoedanigheid van mijnwerker of oud-mijnwerker, een liefst niet te jonge leeftijd ( 25 of 30 jaar) en het gedurende zeker aantal jaren in een nijn gewerkt hebben. Een bepaling als de Fransche wet bevat voor nieuwe mijnen, zou moeielijk gemist kunnen worden.

De verkiesbaarheid van opzichters moet in verband met plantselijke omstandigheden beslist worden. De Fransche Conseil général des mines achtte de maitres-mineurs niet geschikt voor délégué, omdat ze in zekeren zin medebesturen, een opdracht hebben van het mijnbestuur, daardoor aan het toezicht der délégués zijn ouderworpen, zoodat een tot délégué verkozen maitre-mineur tegelijk rechter en partij zou wezen. In België daarentegen schijnt de "surveillant" een andere plaats in de mijn te bekleeden.

Belangrijk is de vraag of de invoering van dit toezicht verplicht zal ziju of niet. In Frankrijk, zagen wij reeds, waren de mijnwerkers ondanks de verplicht-stelling in 28 van de 294 circonscriptions overeengekomen geen délégué te kiezen. De Pruisische Comınissie zag in het verplichte een der hoofdfouten van de Fransche wet. Ook mij kount de Engelsche opvatting

1) In een brief, voorgelezen in den Belgischen Senaat 7 April 1897.

2) In den Rijksdag, 29 Nov. 1899. 
beter voor, volgens welke dit toezicht niet hoeft te bestaan in de mijnen war de arbeiders er geenerlei behoefte aan gevoelen. De geheele Engelsche regeling vooronderstelt echter sterke arbeiders-vereenigingen. Hetzelfde doel schijnt mij bereikbaar door te bepalen dat niemand geacht wordt verkozen te zijn tenzij een zeker gedeelte, b.v. de helft, der ingeschreven kiezers gestemd hebben. Waar dit aantal stemmen niet is uitgebracht, kan men aannemen dat aan het toezicht geen sterke behoefte wordt gevoeld.

De geldelijke regeling in Engeland, uitgaande van het denkbeeld dat de arbeiders, als de meest belanghebbenden bij dit toezicht, het ook maar moeten bekostigen, vooronderstelt eveneens arbeiders-vereenigingen met sterke kassen en een krachtig bestuur. Dergelijke bepaling zou ten onzent, vrees ik, de wet tot een doode letter maken. In Frankrijk betalen de mijneigenaren het. In beginsel moge hiervoor veel te zeggen zijn. Men krijgt de concessie eener mijn onder voorwaarde van zich te gedragen overeenkomstig de bepalingen, in het belang der veiligheid, die de Staat noodig acht. ') Zoo legde ook het Keizerlijk Decreet van 3 Jan. 1813 de verplichting op tot het betalen van chirurgijus en geneesuniddelen. ${ }^{2}$ ) Maar een andere vraag is of het aanbeveling verdient den concessionarissen deze belasting op te leggen voor een toezicht op hun eigen beleid, dat hun toch reeds om verschillende redenen gewoonlijk weinig welkom is. In de derde plaats kan de Stant het betalen. De schatkist toch, heeft voor de kosten van het mijnbeheer, krachtens art. 39 wet van 1810 , een bijzonder fonds, opgebracht door de "redevances" der concessionarissen. Deze oplossing schijnt, wel de beste, en niet zeer bezwarend voor de schatkist, wanneer men bedenkt dat voor geheel Frankrijk de kosten voor 1891 op 200.000 francs geraand werden.

De betaling behoort dan aldus te geschieden, dat de mijnwerker opgeeft hoeveel dagen hij ann bet bezoeken der miju besteed heeft, maar een bedrag dient te worden vasigesteld dat hij op deze wijze hoogstens per maand declareeren kan. Bovendien zullen hem, zoo noodig, reis- en verblijfkosten

1) Verg. art. 50 wet van 21 April 1810.

2) Artt. 15, 16, 17. Zie K. B. van 6 Juli 1877 Artt. 25 en 26. 
vergoed wordeu. Er schijnt me geen reden te bestaan om die vergoeding per dag hooger te stellen dan een gewoon mijnwerkers-dagloon. De Staat behoeft geen premie te stellen op het afleggen van zooveel mogelijk bezoeken.

Het gebied waarover een mijnwerker-opzichter heeft te gaan, kan bij de geringe uitgestrektheid van onze mijnen bij $\mathrm{K}$. $\mathrm{B}$. worden vastgesteld, gelijk in België. In Frankrijk hechten de mijnwerkers veel aan groote circonscriptions, ten einde den délégués meer zelfstandigheid te geven tegenover de werkgevers. Voor de bevoegdheid tot oordeelen daarentegen zal het beter zijn ze klein te maken. Ook deze vraag zal in verband met plaatselijke omstandigheden zijn te beslissen, waarvoor bij een vaststelling door K. B. gelegenheid zal zijn. Bij datzelfde K. B. kan voor ieder gebied bepaald worden, hoeveel hoogstens in een maand aan vergoeding voor afgelegde bezoeken zal worden betaald.

Het toezicht moet zich uitstrekken over de ondergrondsche werken, en boven den grond hoogstens over de lampenkamers. De arbeiders die onder den grond werken, kunnen over de machines en andere inrichtingen b ove $n$ den grond niet oordeelen.

Hoe vaak de bezoeken zullen plaats hebben, zou ik evenals in Engeland aan de mijnwerkers willen overlaten; behoudens de bovengenoemde vaststelling vav een maximum vergoeding per mand. De. wet waarborgt hun het recht van roud te gaan en de Staat vergoedt de kosten, verder staat het aan de arbeiders om hiervan gebruik te maken.

Van ieder bezoek zal een kort verslag moeten worden opgemaakt, welks hoofdpunten de wet zal vaststellen. Het boek waarin deze verslagen worden opgenomen, moet ten allen tijde ter inzage van alle mijnwerkers liggen, en door den Ingenieur bij zijn bezoek worden nagezien. Het zenden van afschriften aan den Ingenieur van al deze verslagen, die dikwijls niets belangrijks zullen bevatten, komt me voor een tijdroovende bezigheid te zijn, die de moeite niet loont. Natuurlijk zal de mijnwerker-opzichter altijd de aandacht van den Ingenieur op het een of ander kunnen vestigen.

Zoowel in Engeland, waar het wél, als in T'rankrijk, waar het niet in de wet staat, wordt de aldus rondgaande mijnwerker begeleid door iemand dien het mijnbestuur aanwijst. Dit brengt mede voorafgaande waarschuwing aan het mijnbestuur, daar 
anders niet altijd iemand ter begeleiding bij de hand zou zijn. In geen van beide kan ik groot bezwaar zieu. Het gevaar dat de waarheid verstopt wordt, is toch bij dit toezicht veel geringer dan bij dat van den Ingenieur.

Den mijnbesturen moet de verplichting worden opgelegd om onmiddellijk van een voorgevallen ongeluk van eenige beteekenis kennis te geven aan den mijnwerker-opzichter, opdat deze dadelijk de plaats kan opnemen en hiervan een verslag opmaken. Voor dit gewichtige deel zijner taak zal hij een afzonderlijke vergoeding moeten genieten.

Eindelijk kan het goed zijn uitdrukkelijk in de wet te vermelden, dat hij den Ingenieur op overtredingen van voorschrifter betreffende mijnpolitie opmerkzaain moet maken. In het algemeen is er veel voor te zeggen om samenwerking met het toezicht der Ingenieurs in de hand te werken, zij het ook niet in de hierarchische verhouding die de Belgische wet schept.

Zooals boven gezegd, behoort het mijnbestuur niet door ontslag een einde te kunnen maken aan de opdracht die een mijnwerker van zijn mede-arbeiders heeft gekregen om voor hun veiligheid te waken. Mocht deze het echter in de nitoefening van zijn toezicht al te bont maken, dan moet er een middel zijn om tusscherbeide te komen, en dat middel is schorsing of afzetting door den Minister, op voorstel vau den Ingenieur. Ook mogen straf bepalingen niet ontbreken tegen belemmeringen aan de uitvoering der wet in den weg gelegd.

Uitvoering der wet. Want een regeling als hier voorgesteld, zal wel het onderwerp eener wet moeten uitmakeu. In den Algemeenen Maatregel dien het onlangs ingediend wetsontwerp in uitzicht stelt, is zij niet op haar plaats. Ook zijn andere strafbepalingen noodig dan dit ontwerp voorziet.

Spoed vereischt deze zaak niet. De teekenen wijzen er op, dat het wel eenigen tijd zal duren eer de mijnnijverheid ten onzent een belangrijke ontwikkeling zal bereiken. Maar toch beeft het zijn nut bijtijds de mantregelen te overwegen, die voor het welzijn der mijnwerkers-bevolking en daardoor voor den bloei dier geheele nijverbeid van vérstrekkende beteekeuis zijn. Dat de invoering van mijnwerkers-toezicht tot die maatregelen behoort, is naar mijne meenig aan geen twijfel onderhevig.

Mr. J. A. N. PatiJn. 